\%

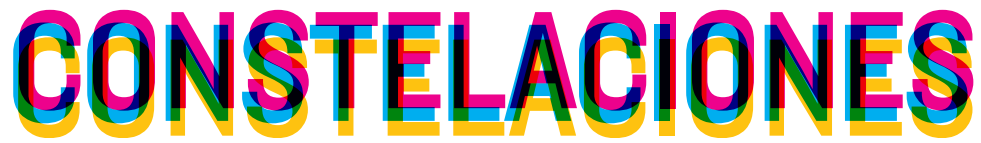

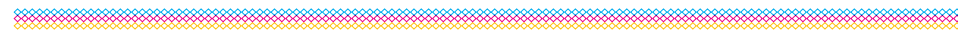


CONSTELACIONES n², mayo 2014

Revista de Arquitectura de la Universidad CEU San Pablo

Architecture Magazine of CEU San Pablo University

Periodicidad anual

Annual periodicity

COMITÉ DE REDACCIÓN EDITORIAL COMMITTEE

\section{Director Director}

Juan García Millán

Jefa de Redacción Editor in Chief

Covadonga Lorenzo Cueva

Secretario de Redacción Editorial Clerk

Rodrigo Núñez Carrasco

Maquetación y producción Design and production

María Fernández Hernández

Vocales Board Members

Fernando del Ama Gonzalo. Escuela Politécnica Superior, Universidad CEU San Pablo, Madrid

Pablo Campos Calvo-Sotelo. Escuela Politécnica Superior, Universidad CEU San Pablo, Madrid

Alfonso Díaz Segura Escuela Superior de Enseñanzas Técnicas, Universidad CEU Cardenal Herrera, Valencia

Mayka García Hípola. Escuela Politécnica Superior, Universidad CEU San Pablo, Madrid

Sonia Izquierdo Esteban. Escuela Politécnica Superior, Universidad CEU San Pablo, Madrid

Javier Sáenz Guerra. Escuela Politécnica Superior, Universidad CEU San Pablo, Madrid

\section{CONSEJO EDITORIAL EDITORIAL BOARD}

Beatriz Colomina. School of Architecture, Princeton University, New Jersey

Carmen Díez Medina. Escuela de Ingeniería y Arquitectura, Universidad de Zaragoza

María Antonia Frías Sargadoy. Escuela Técnica Superior de Arquitectura, Universidad de Navarra

Ángel González García. Facultad de Geografía e Historia, Universidad Complutense de Madrid

Juan Miguel Hernández Léon. Escuela Técnica Superior de Arquitectura, Universidad Politécnica de Madrid

Juan José Lahuerta Alsina. Escuela Técnica Superior de Arquitectura, Universidad Politécnica de Cataluña, Barcelona

Eduardo Leira Sánchez. Ex director del Plan General de Ordenación Urbana, Madrid

Joaquín Medina Wamburg. Facultad de Aquitectura Diseño y Urbanismo, Universidad de Buenos Aires

Zaida Muxí Martínez. Escuela Técnica Superior de Arquitectura, Universidad Politécnica de Cataluña, Barcelona

José Joaquín Parra Bañón. Escuela Técnica Superior de Arquitectura, Universidad de Sevilla

Víctor Pérez Escolano. Escuela Técnica Superior de Arquitectura, Universidad de Sevilla

Fernando Pérez Oyarzún. Escuela de Arquitectura y Diseño, Pontificia Universidad Católica, Santiago de Chile Judith Sheine. School of Architecture and Allied Arts, University of Oregon, Portland

Andrés Walliser Martínez. Global Design, New York University, Nueva York

\section{ISSN 2340-177X}

Depósito legal M-13872-2013

(c) de los textos, sus autores

(c) de las imágenes autorizadas

(c) Revista Constelaciones

๑) Escuela Politécnica Superior, Universidad CEU San Pablo

Universidad CEU San Pablo

Escuela Politécnica Superior

Urbanización Montepríncipe, $s / n$

Boadilla del Monte, 28668. Madrid (España)

constelaciones@eps.ceu.es

www.uspceu.es

Edición Edition

Fundación Universitaria San Pablo CEU

Madrid, España

Impresión Printing

VA Impresores

Impreso en España Printed in Spain

Distribución Distribution

CEU Ediciones

Los textos que componen Constelaciones se obtienen mediante convocatoria pública. Para que los trabajos recibidos entren en el proceso de selección de los artículos a publicar deben ser trabajos originales no publicados anteriormene, con una extensión recomendada de 3.000 palabras, título, resumen (un máximo de 150 palabras) y palabras clave (un mínimo de cuatro palabras), en español y en inglés. Tras haber cumplido estos requisitos (y los correspondientes incluidos en las normas editoriales de la revista, disponibles para consulta en formato digital desde el comienzo de la convocatoria), tiene lugar un proceso de revisión y evaluación de los artículos previa aceptación de los mismos para su publicación. Para acometer dicho proceso, y con el fin de asegurar la calidad de los contenidos, la Revista Constelaciones recurre a evaluadores externos a la institución editora y anónimos (cada artículo es evaluado por dos de ellos) encargados de someter a crítica los mismos. Todos los artículos de investigación publicados en esta revista han pasado por dicho proceso. La recepción de artículos se extendió hasta el 30 de Septiembre de 2013. Texts included in Constelaciones are obtained by public announcement. Only original papers that have not been previously published will be included in the process of selection of articles. They should not exceed 3.000 words and should include a title, an abstract (no more than 150 words) and keywords (a minimum of four words), in Spanish and English. After having fulfilled these requirements (and those included in magazine editorial standards, available for consultation from the beginning of the Call for Papers), occurs a process of review and evaluation of articles upon acceptance of them for publication. To undertake this process, and in order to ensure the quality of the contents, Constelaciones turns to external and anonymous evaluators to the institution (each article is evaluated by two of them) responsible for the critic. All the articles published in this journal have undergone this process. The deadline for reception was extended until September 30, 2013.

Todos los derechos reservados. Esta publicación no puede ser reproducida, ni en todo ni en parte, ni registrada, ni transmitida, ni almacenada en ningúna forma ni por ningún medio, sin la autorización previa y por escrito del equipo editorial. En este número se han utilizado algunas imágenes de las que no se ha podido identificar al propietario de los derechos. En estos casos hemos entendido que las imágenes son de libre uso. En caso de identificar alguna de estas imágenes como propia, por favor, póngase en contacto con la redacción de Constelaciones. Los criterios expuestos en los diversos artículos de la revista, son responsabilidad exclusiva de sus autores, y no reflejan necesariamente los que pueda tener el equipo editoral. El equipo editorial de la revista no se responsabiliza de devolver la información enviada a la redacción a no ser que se le solicite expresamente. All rights reserved. This publication cannot be reproduced, in whole or in part, nor registered, transmitted or stored in any form or by any means, without the written permission of the Editorial team, In this issue some images were used without knowing the owner of the rights. In these cases, we have understood that the images are free of use. In case you identify written permission of the Editorial team, In this issue some images were used without knowing the owner of the rights. In these cases, we have understood that the images are free of use. In case you identify
any of these images as your own, please, contact with the Editorial staff of Constelaciones. The opinions expressed in this issues's articles are entirely the responsibility of their authors and are not necessarily shared by the editors of this journal. The publisher don't take responsibility for returning submitted material which is not expressly requested. 


$$
11
$$




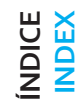

$\stackrel{n}{\sim}$

ร

5

$\curvearrowright$

๙ิ

$\stackrel{n}{=}$

$\bar{m}$
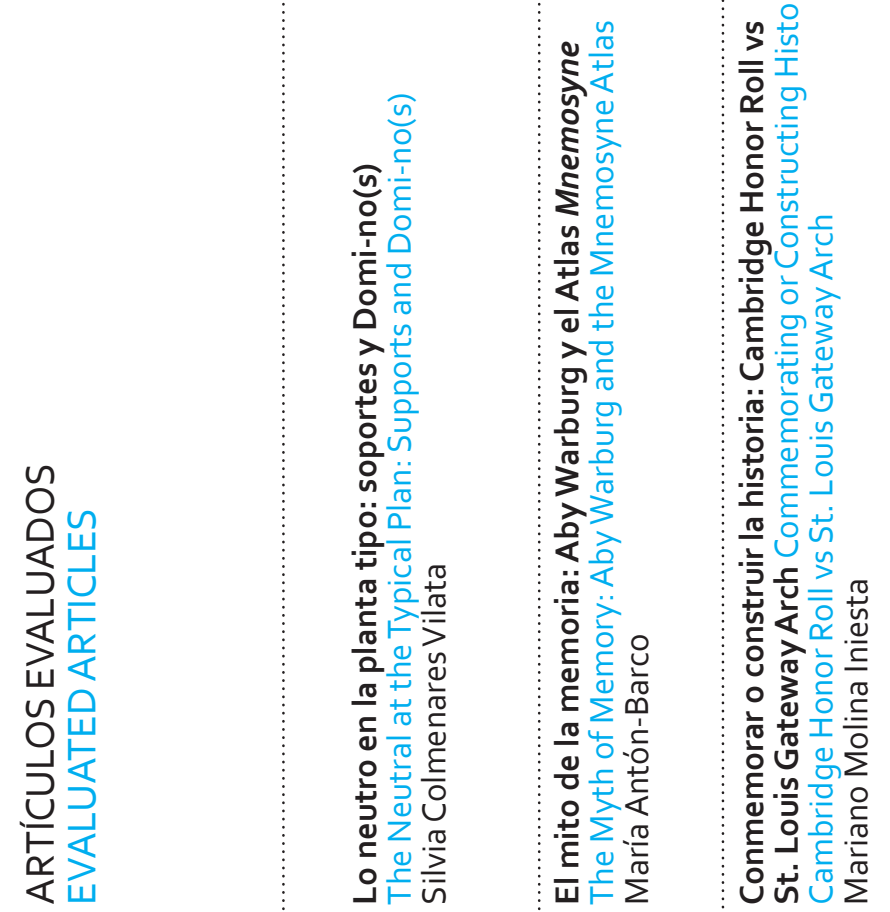

旁 을

‥

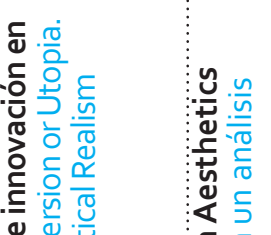

앙

胥苞

$\bar{\Psi}$

宛

일

능홍

区告

음 흠

응 흥

\%

든

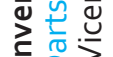

ข

음

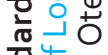

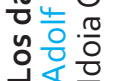

a व

은

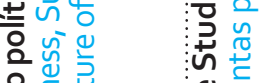

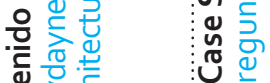

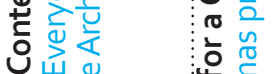

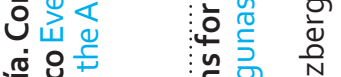

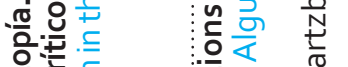

गे

गे० गे ये ज

:

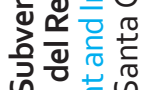

है

ज०

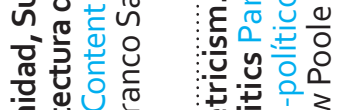

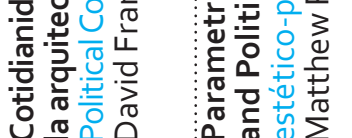

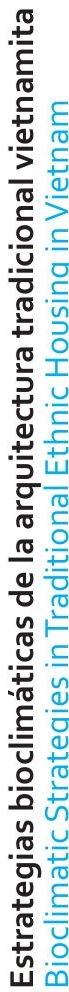

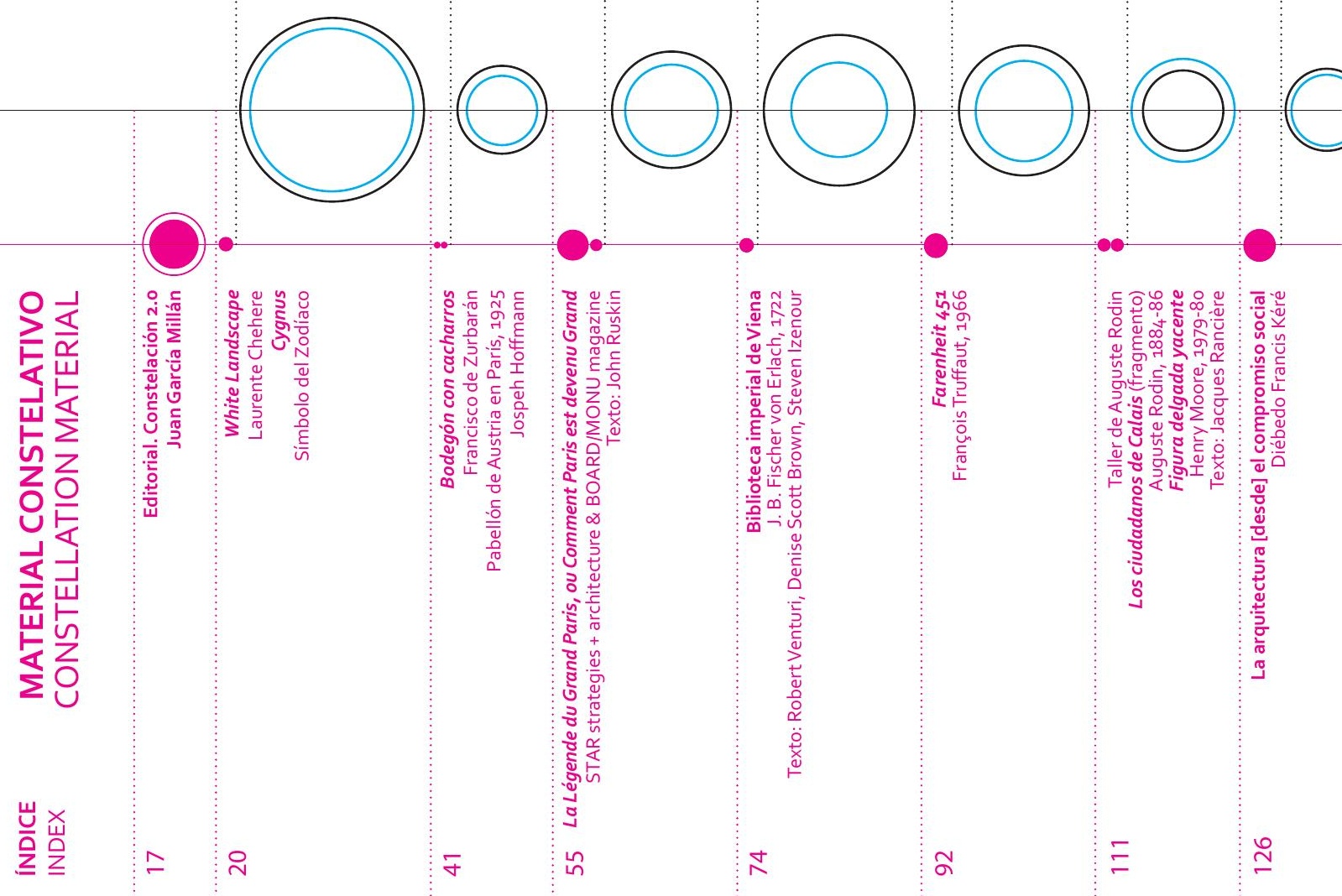

苍

० 


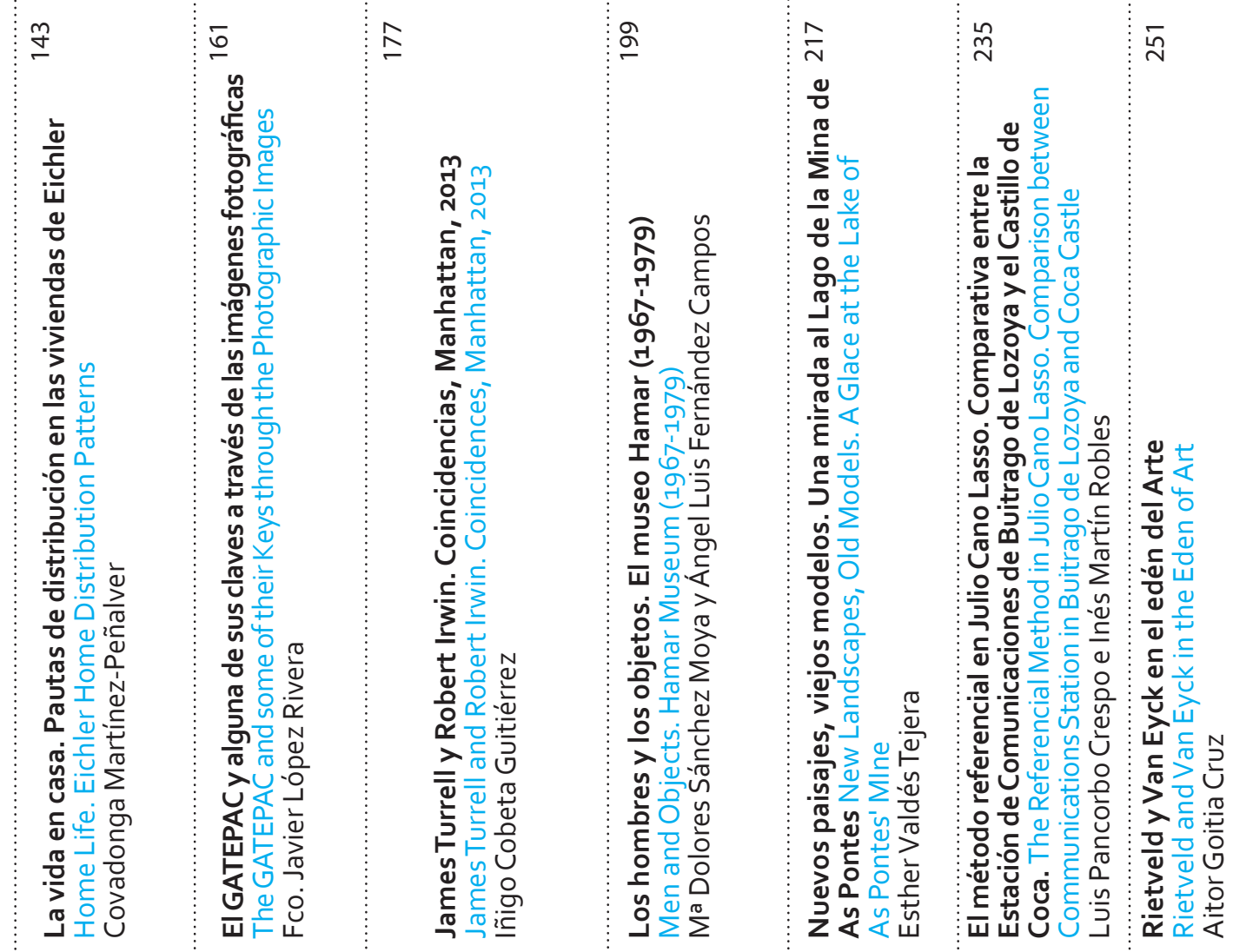
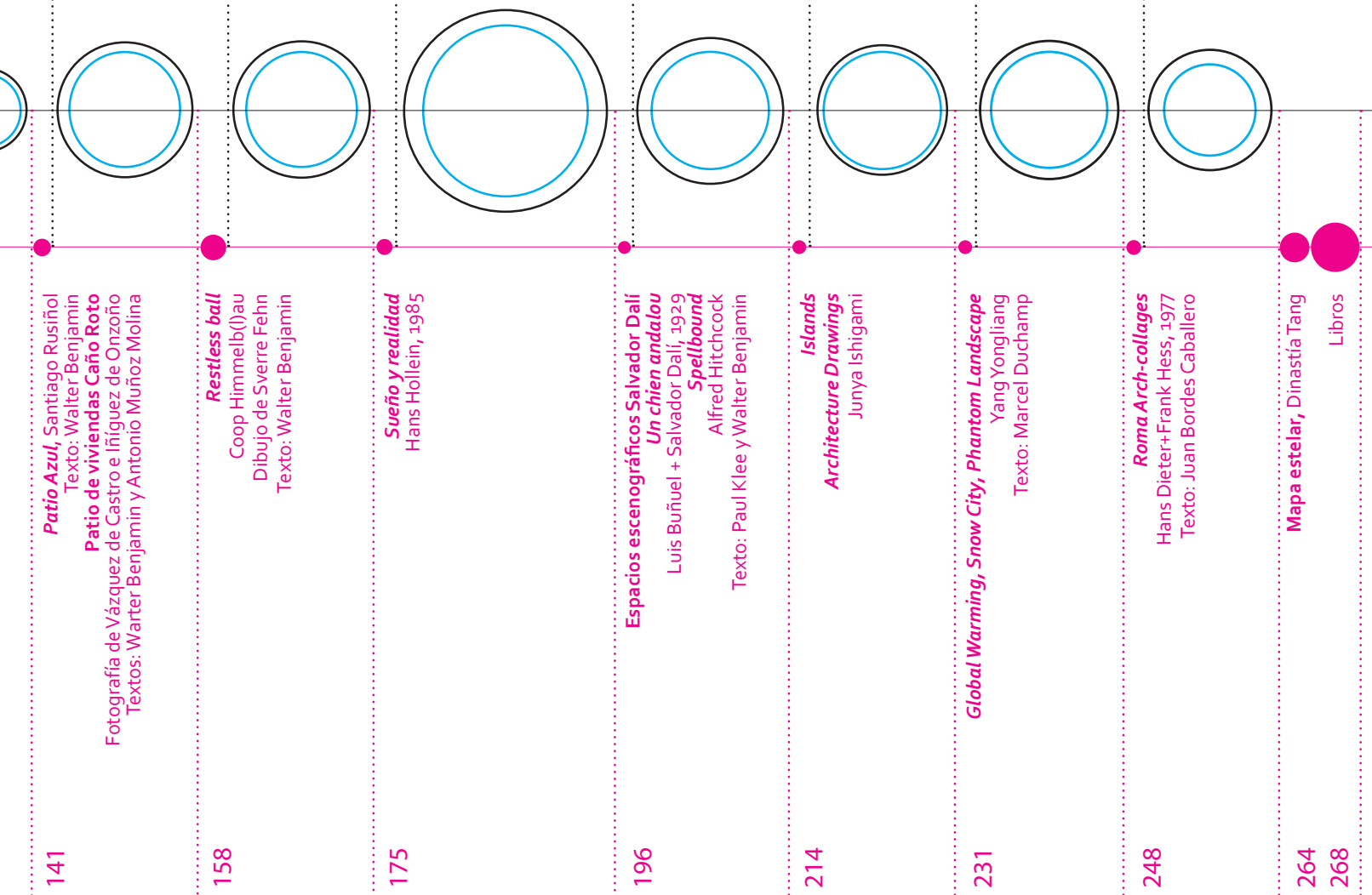


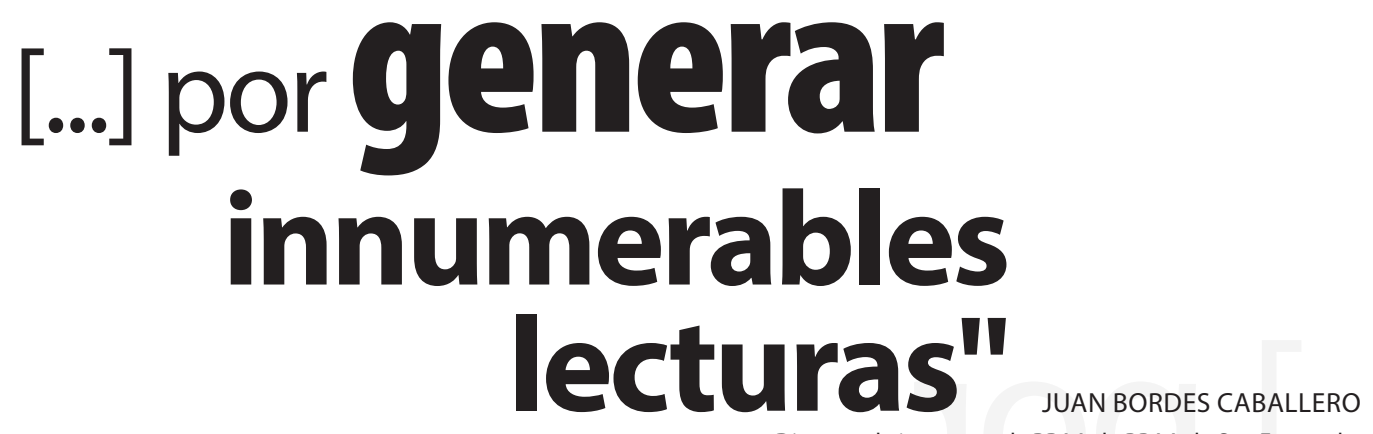

Discurso de ingreso en la RRAA de BBAA de San Fernando.

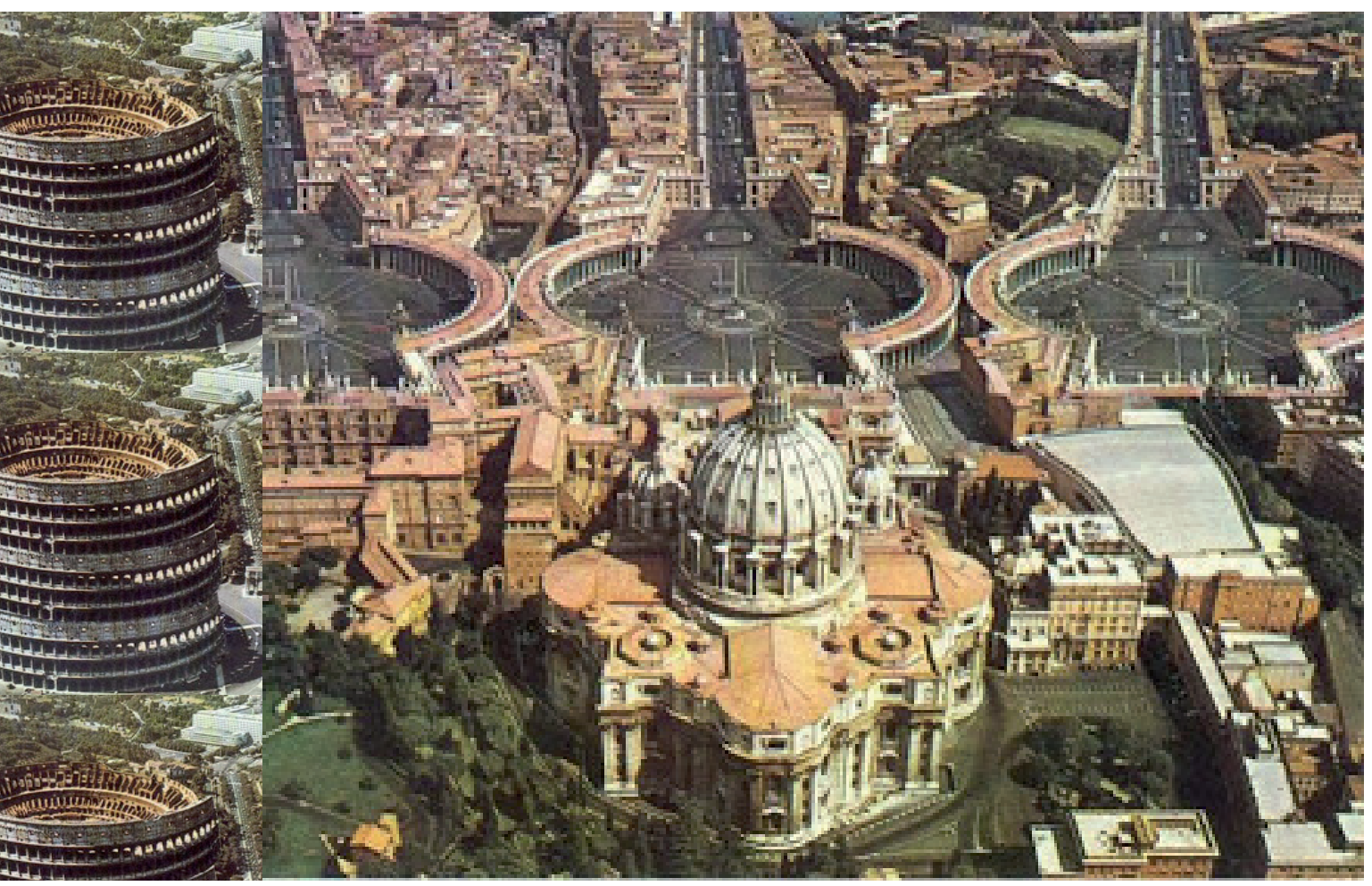




\section{Rietveld y Van Eyck en el edén del Arte Rietveld and Van Eyck in the Eden of Art}

\section{Aitor Goitia Cruz}

Escuela Politécnica Superior, Universidad CEU San Pablo, Madrid

Traducción Translation Linda Hamalainen

\section{Palabras clave Keywords}

Rietveld, Van Eyck, Kröller-Müller, Sonsbeek, pabellón, exposición, reconstrucción

Rietveld, Van Eyck, Kröller-Müller, Sonsbeek, pavilion, exhibition, rebuilding

\section{Resumen}

Los jardines del museo Kröller-Müller de Otterlo alojan las reconstrucciones de los pabellones que Rietveld y Van Eyck construyeron en 1955 y 1966, para la Exposición Internacional de Escultura del parque Sonsbeek de Arnhem. Esta comunicación relata el proceso de formación del museo y la reciente historia de reconstrucción de los pabellones integrados en él.
Abstract

The Kröller-Müller Museum gardens in Otterlo host the reconstructions of the pavilions built by Rietveld and Van Eyck in 1955 and 1966 for the International Exhibition of Sculpture in Sonsbeek Park, Arnhem. This paper describes the museum formation process and the recent history of reconstruction of the pavilions integrated on it. 
Los caprichosos pliegues del tiempo y del espacio han querido reunir en los jardines del Museo Kröller-Müller dos obras maestras de los arquitectos holandeses más reconocidos del pasado siglo xx. En pleno Parque Nacional Hoge Veluwe, los terrenos de la institución que alberga una de las colecciones privadas de arte moderno más extensas del mundo han acogido como propios los pabellones que Gerrit Rietveld y Aldo van Eyck construyeron con motivo de la tercera y quinta Exposición Internacional de Escultura, celebradas en el Parque Sonsbeek de Arnhem en 1955 y 1966 respectivamente.

La reconstrucción de estas arquitecturas efímeras -a escasos kilómetros de su ubicación inicial, en un entorno de similares características, y destinadas a los mismos fines para los que fueron concebidas- sugiere oportunas reflexiones acerca de la vigencia de su diseño y sobre la conveniencia, o no, de perpetuar su memoria mediante la recreación de unas construcciones proyectadas con fecha de caducidad. Al margen de tales conjeturas, la conmovedora realidad actual constituye una simbiosis irrepetible entre arte y naturaleza, lograda en un hábitat moldeado con esmero desde 1938, cuando abría sus puertas el Museo Kröller-Müller, que ha sabido incorporar la arquitectura y el paisaje a los fondos de su colección.

Una casa en el bosque. Helene Müller comenzó a adquirir obras de arte en 1905, gracias a la desahogada economía que le procuraba el negocio familiar -la compañía Wm. H. Müller \& Co- que dirigía desde 1889 Anton Kröller, con quien se había casado un año antes. Asesorada por Hendricus Petrus Bremmer llegó a reunir a lo largo de su vida más de 11.500 objetos de arte, entre los que destacan 185 dibujos y 97 pinturas de su artista favorito, Vincent Van Gogh.

Durante un viaje a Florencia en 1910, conmovida por el esplendor artístico y el mecenazgo de los Medici, concibió la idea de crear una residenciamuseo para promover el acercamiento del arte moderno al gran público. (1) Un año después, los Kröller-Müller pidieron a diversos arquitectos que diseñaran una casa-galería que debía construirse en Ellenwoude, el nombre que dieron a los terrenos que acababan de adquirir en Wassenaar, cerca de La Haya. Indecisos ante las propuestas de Peter Behrens o Hendrik Petrus

The capricious folds of time and space have wished to reunite two masterpieces of the most famous Dutch architects of the 20th century in the gardens of the Kröller-Müller Museum. Hoge Veluwe National Park, the lands of the institution that houses one of the most extensive private collections of modern art in the world, has welcomed the pavilions that Gerrit Rietveld and Aldo van Eyck built for the Third and Fifth International Exhibition of Sculpture, celebrated in Arnhem's Sonsbeek Park in 1955 and 1966, respectively.

The reconstruction of these ephemeral works of architecture, located a few kilometres from their original location, in a setting of similar characteristics and destined to the same ends for which they were conceived, suggests opportune reflections on the validity of their design and the convenience, or not, of perpetuating their memory with the recreation of constructions projected with an expiration date. Aside from these conjectures, the poignant present reality constitutes a unique symbiosis of Art and Nature, achieved in a habitat moulded with great care since 1938, when the Kröller-Müller Museum, knowing how to incorporate architecture and countryside, opened its doors to the essence of its collection.

A House in the Forest. Helene Müller began to acquire works of art in 1905, thanks to the healthy economic situation of the family business Wm. H. Müller \& Co, directed by her husband Anton Kröller since 1889. Advised by Hendricus Petrus 
Berlage, Anton Kröller forzó la construcción de maquetas a gran escala, de modo que facilitasen su elección.

La señora Kröller-Müller, insatisfecha con el concepto de Behrens, propuso al asistente de éste, Mies van der Rohe, que realizara una nueva propuesta. Independizado laboralmente de su mentor a principios de 1912, Mies aceptó el encargo y elaboró un nuevo proyecto con el que competir en septiembre con Berlage, en quien recaería la designación final tras la ruda mediación de Bremmer, asesor artístico en todo el proceso. (2) El proyecto nunca llegó a realizarse, ya que los Kröller-Müller vendieron su propiedad ante los rumores de la construcción en sus proximidades de una línea de ferrocarril. Como compensación, Berlage recibirá continuados encargos para Wm. H. Müller \& Co, y para la familia propietaria de la compañía. (Figs. 1, 2)

El matrimonio Kröller-Müller dirigió entonces su interés a la boscosa región de Veluwe, a media distancia entre las localidades de Apeldoorn y Arnhem. Anton soñaba con formar una gran reserva de caza y Helene perseguía construir un gran museo para mostrar su colección y una residencia privada anexa. Ambas
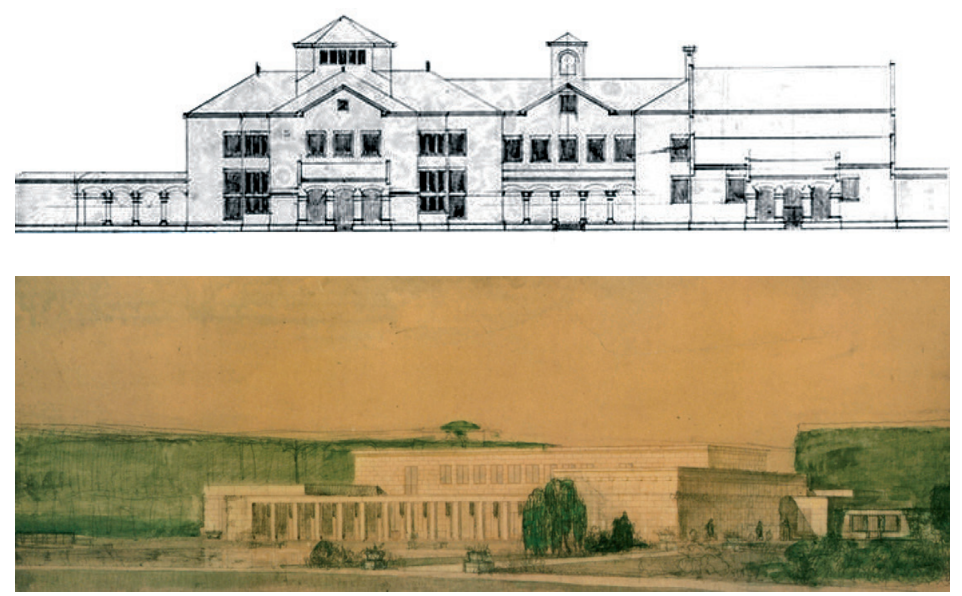

Fig. 1. Berlage, Hendrik Petrus: Casa-museo Kröller-Müller en Wassenaar, 1912. Netherlands Architectuurinstituut.

Fig. 2. Mies van Der Rohe, Ludwig: Casamuseo Kröller-Müller en Wassenaar, 1912. Kröller-Müller Museum, Otterlo.

Bremmer throughout her life, she managed to gather more than 11,500 art objects, among which stand out 185 drawings and 97 paintings of her favourite artist, Vincent Van Gogh.

During a trip to Florence in 1910, moved by the artistic splendour and patronage of the Medici, she conceived the idea of creating a museum-residence to promote the approach of modern art to the general public. (1) The following year, the Kröller-Müllers asked diverse architects to design a house-gallery to be constructed in Ellenwoude, the land that they had acquired in Wassenaar, near the Hague. Doubting between the proposals of Peter Behrens or Hendrik Petrus Berlage, Anton Kröller obliged them to construct large-scaled models to facilitate the choice.

Mrs. Kröller-Müller, unsatisfied with Behrens' concept, proposed to Mies van der Rohe, his assistant, that he develops a new proposal. Independent of his mentor from the beginning of 1912, Mies accepted the idea and in September elaborated a new project with which to compete with Berlage, upon who would fall the final designation, after the rude mediation of Bremmer, artistic assessor in the entire process. (2) The project was never carried out, as the KröllerMüllers, faced with the rumours of the construction of a railroad line nearby, sold their property. In compensation, Berlage would receive continuous commissions from Wm. H. Müller \& Co, and from the family, which was the owner of the company. (Figs. 1,2) 
cosas fueron posibles en las 6.000 hectáreas que la pareja logró reunir en pocos años. Berlage construyó al borde de un lago artificial una lujosa residencia para los Kröller, concluida en 1920 y bautizada como Pabellón de Caza San Huberto, y dieciocho años más tarde se inauguraba el museo de arte moderno.

Abandonado el proyecto de Ellenwoude, Helene Kröller-Müller había transformado en 1913 la primera planta de la sede de Wm. H. Müller \& Co en una sencilla galería que exhibía parte de su colección a los escasos

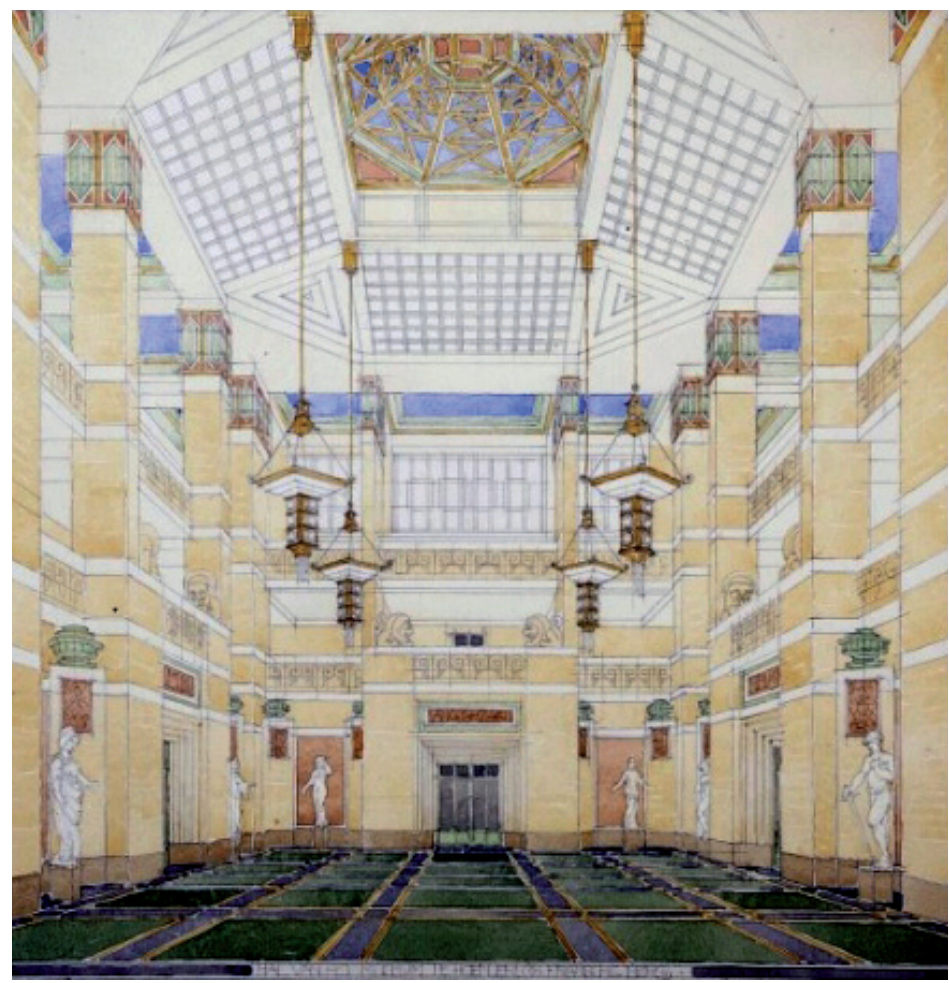

Fig. 3. Berlage, Hendrik Petrus: Proyecto de Museo en Hoge Veluwe, 1917. Vistas del vestíbulo, acceso este y patio de flores. KröllerMüller Museum, Otterlo.
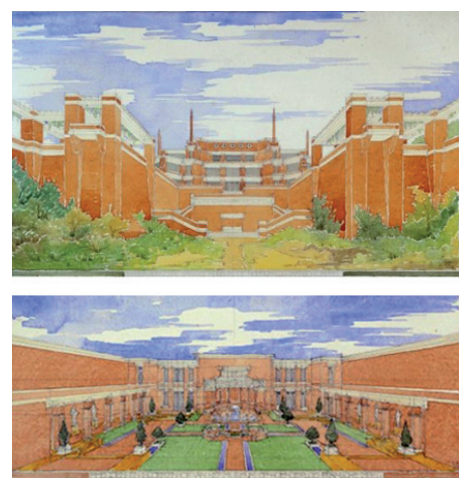

The Kröller-Müllers then directed their interests to the forest region of Veluwe, midway between the towns of Apeldoorn and Arnhem. Anton dreamed of creating a hunting reserve and Helene continued thinking about creating a large museum to exhibit her collection and annexing a private residence. Both ideas were possible in the 6,000 hectares that the couple managed to unite in a few years. Berlage constructed a luxurious residence for the Kröllers next to an artificial lake, finished in 1920, and baptised as the San Humberto Hunting Pavilion. Eighteen years later, the museum of modern art was inaugurated.

In 1913, having abandoned the project of Ellenwoude, Helene Kröller-Müller had transformed the first floor of the headquarters of Wm. H. Müller \& Co into a simple gallery that exhibited part of her collection to the few citizens of the Hague who had previously solicited an appointment. The land of Veluwe seemed to assure the definitive opportunity for the construction of a museum of large dimensions, where one could exhibit the wonders of modern art to the general public. In 1917, Berlage wrote a complex, elaborate proposal, but the disagreements with Mrs. Kröller-Müller brought this project to a frustrating end and the architect abruptly broke off all relationship with his clients. (Fig. 3)

It was at that time when Helene solicited the services of the Belgian architect, Henry van de Velde, who would be impressed by the plans of the collector and charmed by the location of Veluwe, which he had no doubt in qualifying as Paradise. 


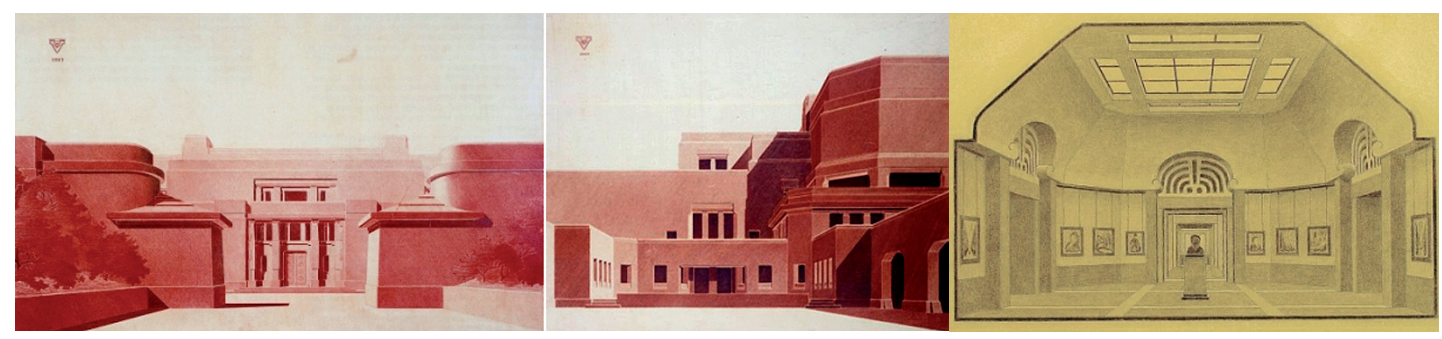

ciudadanos de La Haya que lo solicitaban previamente. Los terrenos de Veluwe parecían asegurar la oportunidad definitiva para la construcción de un museo de grandes dimensiones donde mostrar al gran público las bondades del arte moderno. Berlage redactó en 1917 una compleja y elaborada propuesta, pero las desavenencias con la señora Kröller-Müller malograron el proyecto y el arquitecto rompió abruptamente toda relación con sus empleadores. (Fig. 3)

Fue entonces cuando Helene solicitó los servicios del belga Henry van de Velde, quien quedaría impresionado por los planes de la coleccionista y seducido por el emplazamiento de Veluwe, que no dudó en calificar como 'el paraíso'. Van de Velde trabajó durante años en un ambicioso diseño que incluía, además de un extenso museo, salas de conferencias, biblioteca, un gran patio de honor y las dependencias privadas de los Kröller-Müller. Apenas comenzadas las obras del gran edificio, a escasos cinco kilómetros del Pabellón San Huberto de Berlage, la construcción quedó paralizada debido a la recesión internacional que afectó gravemente a las finanzas de los Kröller-Müller, quienes salvaron su colección de arte mediante la creación en 1928 de una fundación. (Fig. 4)

Poco tiempo después, la incansable Helene Kröller-Müller instaba a Van de Velde a proyectar un edificio de menores dimensiones mientras obtenía de Henri Marchant, Ministro de Educación, Artes y Ciencias, el compromiso del gobierno holandés para llevarlo a cabo, a cambio de la donación al estado de todos los fondos de su colección. Junto a los cimientos del proyecto

Fig. 4. Van de Velde, Henry: Proyecto de Museo en Hoge Veluwe, 1921-26. Vistas de la entrada principal, la galería y el acceso norte. Kröller-Müller Museum, Otterlo.

Van de Velde worked for years on an ambitious design that included an extensive museum, conference rooms, a library, a large main courtyard and the private housing dependencies of the Kröller-Müllers. However, hardly had the work begun, just five kilometres from the San Humberto Pavillion of Berlage, when it was paralysed, due to the international recession which greatly affected the finances of the Kröller-Müllers. They managed to save their collection of art via the creation of a foundation in 1928. (Fig. 4)

Shortly after, the tireless Helene Kröller-Müller encouraged Van de Velde to design a smaller building, while obtaining from Henri Marchant, Minister of Education, Science and Art, the compromise of the Government of Holland to complete it, in return for the donation of all of the works in the collection to the state. Next to the foundations of the initial project, the construction of a provisional museum began in 1935. This would end up being the definitive one, after the diverse transformations and amplifications brought about since its inauguration.

The first of these transformations took place in 1953, when Van de Velde himself added a sculpture gallery and a new wing for the celebration of conventions. Re-baptised as the Rijksmuseum Kröller-Müller after the death of its promoter and first director in 1939, the museum had specialised in modern sculpture under the direction of A.M. Hammacher, 
inicial, comenzaba en 1935 la construcción de un museo provisional, que acabará siendo definitivo después de las diversas transformaciones y ampliaciones llevadas a cabo desde su inauguración.

La primera de ellas tuvo lugar en 1953, cuando el propio Van de Velde añadía una galería de escultura y una nueva ala para la celebración de congresos. Rebautizado como Rijksmuseum Kröller-Müller tras el fallecimiento en 1939 de su promotora y primera directora, el museo se había especializado en escultura moderna bajo la dirección de A.M. Hammacher, que deseaba espacios amplios y bien iluminados para exponer piezas de gran tamaño. Completando sus deseos, en 1961 se inauguraba el Jardín de Esculturas, diseñado por Jan Tijs Pieter Bijhouwer, quien dispuso con sumo acierto piezas de Rodin, Moore, Hepworth y otros artistas en perfecta sintonía con el paisaje circundante.

Algo más tarde, el director Rudi Oxenaar, convencido de las limitaciones técnicas y espaciales de un museo concebido como provisional, promovió una gran ampliación consistente en nuevas salas de grandes dimensiones y galerías acristaladas en contacto con los jardines. En 1977 se inauguraban las modernas dependencias, proyectadas por Wim Quist. El edificio original de Van de Velde fue posteriormente objeto de una intervención integral, cuando en 2005 se renovaron las cubiertas y los sistemas de captación lumínica y de protección contra el fuego.

Al mismo tiempo, el Jardín de Esculturas fue incrementando el número de piezas, estratégicamente dispuestas en las praderas, entre los grupos de árboles o junto al estanque próximo a la edificación principal. Tras constantes variaciones, el jardín hubo de reordenarse atendiendo a criterios expositivos, como los de cualquier otra sala del museo. A partir de 1990, la directora Evert van Straaten diseñó un plan director en colaboración con los arquitectos y paisajistas West 8 , cuya puesta en práctica concluía en el verano de 2002, con la reapertura al público de las 25 hectáreas destinadas a la interacción del espectador con las obras de arte en el medio natural. (Figs. 5, 6)

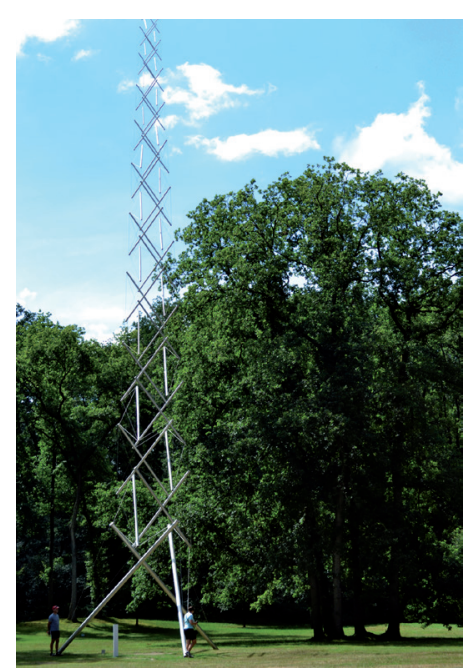

Fig. 5. Snelson, Keneth: Needle tower, 1968. Kröller-Müller Museum, Otterlo. Fotografía del autor, 2013.

who desired ample, well-illuminated spaces to exhibit large-sized pieces. Fulfilling his wishes, the Garden of Sculptures, designed by Jan Tijs Pieter Bijhouwer, who skilfully placed works of Rodin, Moore, Hepworth and other artists in perfect tuning with the surrounding countryside, was inaugurated in 1961.

Sometime later, the director Rudi Oxenaar, convinced of the technical and spatial limitations of a museum conceived as provisional, promoted an extensive amplification, consisting of new rooms of large dimensions and glazed galleries in contact with the gardens. In 1977, the modern dependencies projected by Wim Quist were inaugurated. Van de Velde's original building was later object of an integral intervention. In 2005, the roofs and the systems of fire protection and of captivation of light were modernized.

At the same time, the number of pieces in the Garden of Sculptures, strategically placed in the meadows, between groups of trees, or next to the pond by the principal building, was growing. After constant variations, it was necessary to re-order the garden, bearing in mind criteria of exhibition, just as in any other room in the museum. Beginning in 1990, the director Evert van Straaten designed a plan in collaboration with the architects and landscape artists West 8 , concluded in the summer of 2002 , when the 25 hectares destined to the interaction of the spectator with works of art in a natural medium were re-opened to the public. (Figs. 5, 6) 


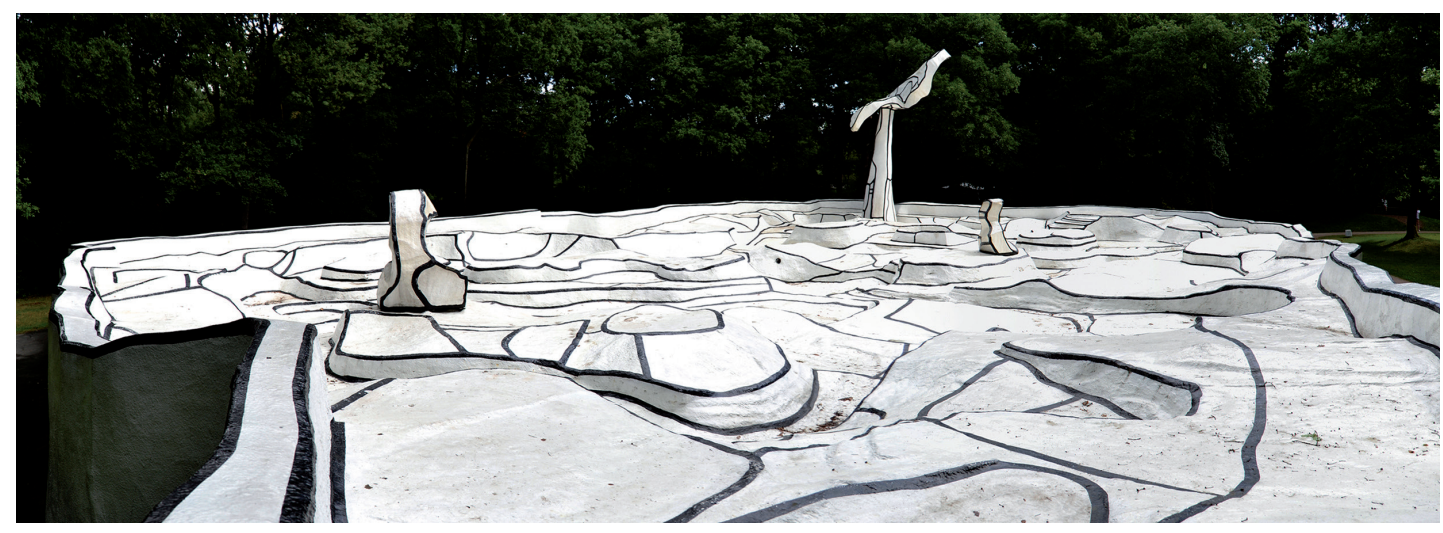

La reconstrucción en este paraíso de los pabellones de Van Eyck y Rietveld viene a completar un proceso transformador de una naturaleza enriquecida por la aparición inesperada de piezas de Richard Serra, Jean Dubuffet, o Fig. 6. Dubuffet, Jean: Jardin d'émail, 1974. Kröller-Müller Museum, Otterlo. Fotografía del autor, 2013. Kenneth Snelson. Arquitecturas como esculturas y viceversa, desdibujan las sutiles líneas divisorias entre ambas disciplinas, totalmente integradas en este meticuloso edén del arte, la última expansión del museo ideado por Helene Kröller-Müller.

Los pabellones Sonsbeek. El parque Sonsbeek, en la localidad holandesa de Arnhem, viene acogiendo con irregular periodicidad la convocatoria de una exposición internacional de escultura, consolidada como una cita ineludible con el arte contemporáneo. La primera edición data de 1949, siendo la décima -y última hasta la fecha- la celebrada en 2008 bajo el lema 'Grandeur'. El evento ha reunido a lo largo del tiempo manifestaciones artísticas de todo tipo y en 1955, 1966 y 1986 se requirió la construcción de pabellones temporales, que fueron desmontados al finalizar el tiempo de exposición correspondiente.

El pabellón de 1955 fue concebido por Gerrit Thomas Rietveld durante un viaje en tren, según confesaba su autor algunos años más tarde. (3) Una

The reconstruction of the pavilions of Van Eyck and Rietveld in this paradise completes the transformation process of enriching Nature with the unexpected appearance of works of Richard Serra, Jean Dubuffet, or Kenneth Snelson. Architecture as sculpture and vice-versa, blend the subtle dividing lines between the two disciplines, totally integrated in this meticulous Eden of Art, the final expansion of the museum devised by Helene Kröller-Müller.

The Sonsbeek Pavilions. Sonsbeek Park, in the Dutch town of Arnhem, has been holding the convocation of an international exhibition of sculpture, considered as an indispensable date with contemporary art, at irregular periods. The first edition was held in 1949, and the 10th and last to date, 'Grandeur', in 2008. Throughout time, the event has congregated artistic manifestations of all nature and in 1955, 1966, and 1986, temporary pavilions of different kinds were constructed, and later, deconstructed at the end of the exhibitions.

The pavilion of 1955 was conceived by Gerrit Thomas Rietveld during a train ride, as he confessed some years later. (3) A tiny model of cardboard was sufficient to conceive the subtle spatial configuration with which he created the project. The concise drawings conserved in the Rietveld Schröderarchief of the Centraal Museum of Utrecht and a second model, guarded by the Stedelijk Museum of Amsterdam, hardly specify the contours and proportions of that first composition. 
diminuta maqueta de cartón bastó para idear la sutil configuración espacial con que ideó su proyecto. Los escuetos dibujos conservados en el Rietveld Schröderarchief del Centraal Museum de Utrecht y una segunda maqueta custodiada en el Stedelijk Museum de Amsterdam apenas precisan los contornos y proporciones de aquella primera composición. Las manos del artesano bastaron para dar forma a la propuesta, reemplazando las habilidades gráficas de un arquitecto consagrado desde que construyera en décadas anteriores obras tan destacadas como la Casa Schröder o el Museo Van Gogh. (Fig. 7)

Defensor de la arquitectura como arte plástica, (4) Rietveld encontró en Sonsbeek la oportunidad que no tuvo el año anterior cuando construyó el pabellón holandés para la bienal de Venecia, un edificio proyectado con los útiles convencionales del arquitecto y destinado a garantizar, mediante límites precisos, el cobijo de su cambiante contenido. El Pabellón de Arnhem, en cambio, establece apenas un marco de referencia para un espacio dinámico de imposible delimitación. Rectas y planos flotantes constituyen una composición escultórica construida con bloques perforados de hormigón en los muros, cubiertas de madera y medidos paños de vidrio con los que protegerse del viento en sus galerías, de tres metros de ancho, o en el espacio central de doce por doce metros. (Fig. 8)

Transcurrido el tiempo de la exposición, el pabellón fue desmantelado, aunque debido a su gran éxito no tardaron en llegar iniciativas para su reconstrucción. En 1960, el ingeniero W. A. den Bakker, director del Eerste Nederlandse Coöperatieve Kunstmestfabriek quiso reedificarlo en Vlaardingen, pero razones económicas impidieron que lo lograra. Poco después, el consejo de administración de la fábrica textil De Ploeg consideró situar el pabellón en sus terrenos de Bergeyk, aunque abandonaron su idea cuando un grupo de arquitectos liderados por W. van Tijen y S. J. van den Embden sugirieron su reconstrucción en el parque del Museo Kröller-Müller.

Antes de fallecer en 1964, Gerrit Rietveld pudo escoger el emplazamiento para la reinstalación de su pabellón, completada un año más tarde. Era la pri-

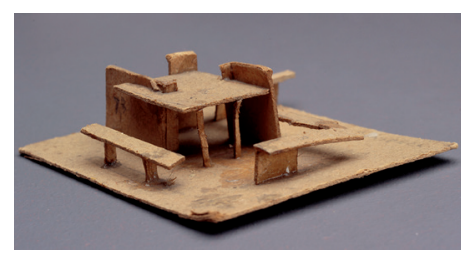

Fig. 7. Rietveld, Gerrit Th.: Maqueta para el pabellón de esculturas del Parque Sonsbeek de Arnhem, 1955. Rietveld Schröderarchief, Centraal Museum, Utrecht. Fotografía, Ernst Moritz

The hands of the artisan were sufficient to give form to the idea, substituting the graphic abilities of the architect, consecrated since he had constructed, decades before, such outstanding works as the Schröder House and the Van Gogh Museum. (Fig. 7)

A defender of architecture as a plastic art, (4) Rietveld found in Sonsbeek the opportunity that he did not have the previous year when he constructed the Dutch pavilion for the biennial in Venecia: a building projected with the conventional tools of the architect and destined to guarantee, within precise limits, shelter for its ever-changing content. The Arnhem Pavilion, on the other hand, hardly establishes a mark of reference for the dynamic space of impossible delimitation. Straight lines and floating planes constitute a sculpture-like composition constructed with concrete hollow blocks for the walls, covered with wood and precise glass panes with which to protect oneself from the wind in the galleries, three metres wide, or in the central space of 12 by 12 metres. (Fig. 8)

Once the exhibition was over, the pavilion was dismounted. However, because of its great success, it wasn't long before initiatives for its reconstruction appeared. In 1960, W. A. den Bakker, engineer and director of the Eerste Nederlandse Coöperatieve Kunstmestfabriek, wanted to re-build it in Vlaardingen, but economic factors impeded the process. A short 
mera vez en la historia de la arquitectura holandesa que arquitectos y empresarios reconstruían un edificio con el único propósito de rendir homenaje a su creador. Una placa colocada junto al nuevo pabellón de 1965 así lo recordaba: "Fue el deseo combinado de muchos de sus colegas y amigos para honrar a su manera al hombre que demostró con su edificio cómo la arquitectura puede tener un efecto esclarecedor, purificador y alentador sobre nuestras vidas".

Unos meses después Aldo van Eyck se enfrentaba a un reto singular. Debía construir el pabellón para la exposición Sonsbeek de 1966, a unos veinte kilómetros de distancia de la reconstrucción del de 1955. Van Eyck admiraba en Rietveld las cualidades artísticas que se negaba a conceder al común de los arquitectos. (5) Las palabras de la inscripción junto al pabellón de Rietveld parecían resonar en su interior y, más que resolver un proyecto, Van Eyck debía medirse con la historia reciente de la arquitectura holandesa.

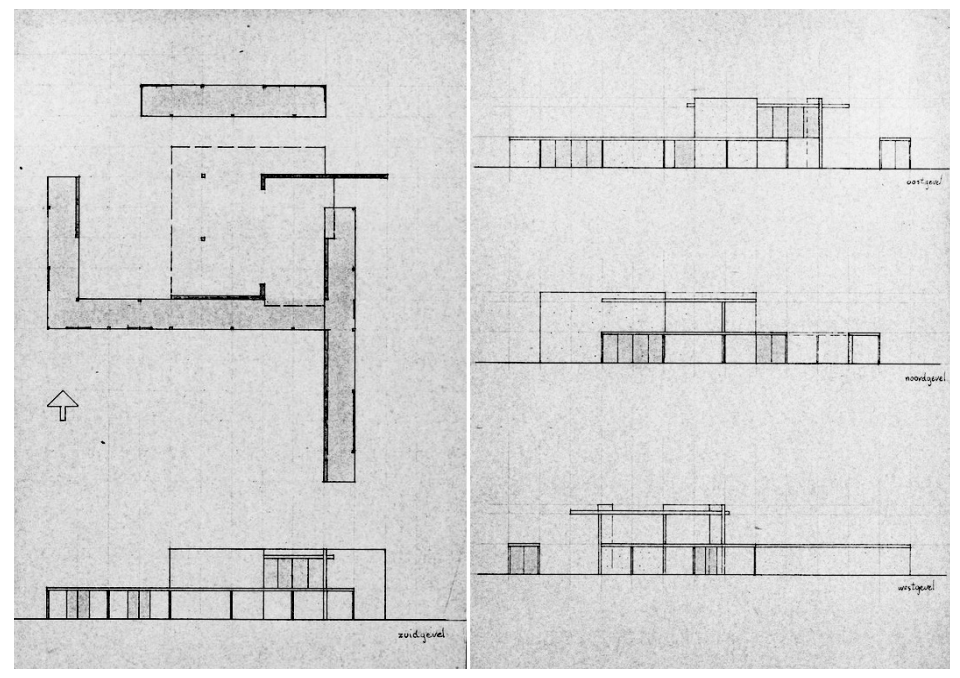

Fig. 8. Rietveld, Gerrit Th.: Planta y alzados para el pabellón de esculturas del Parque Sonsbeek de Arnhem, 1955. Rietveld Schröderarchief, Centraal Museum, Utrecht.

time after, the board of directors of the De Ploeg textile factory considered situating the pavilion in Bergeyk's terrains, although they abandoned the idea when a group of architects, led by W. van Tijen and S. J. van den Embden suggested the reconstruction in the park of the Kröller-Müller Museum.

Before his death in 1964, Gerrit Rietveld was able to choose the site for the reinstallation of the pavilion, completed a year later. It was the first time in the history of Dutch architecture that architects and businessmen reconstructed a building with the sole intention of paying homage to its creator. A plaque situated next to the new pavilion in 1965, recalls this: "It was the combined desire of many of his colleagues and friends to honour, in their way, the man who showed, with his building, how architecture can lend a clarifying, purifying, uplifting, and inspiring effect to our lives".

A few months later, Aldo van Eyck experienced a singular challenge. He had to construct the pavilion for the Sonsbeek exposition of 1966, some twenty kilometres from the reconstruction of 1955. Van Eyck admired the artistic qualities of Rietveld, which he refused to grant to the common body of architects. (5) The words of inscription next to the Rietveld Pavilion seemed to resound in his interior and, more than resolve a project, Van Eyck had to measure himself against the recent history of Dutch architecture. 


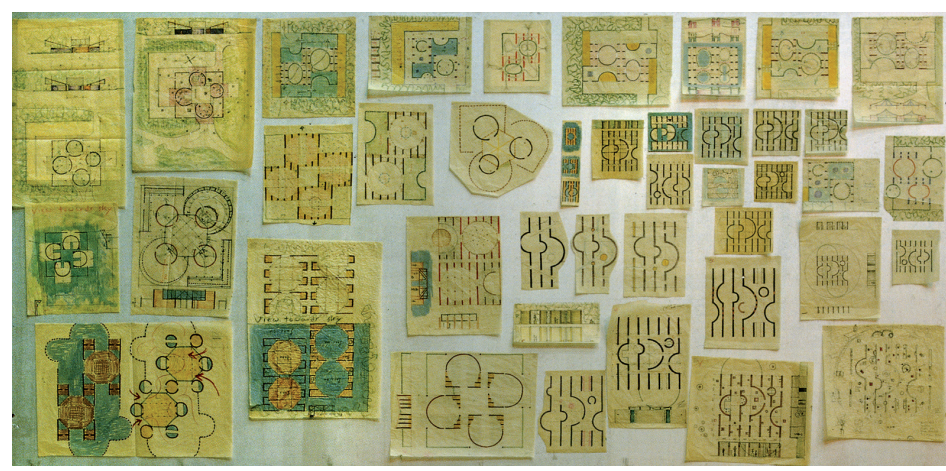

Frente a la lucidez de un inspirado Rietveld, cuyo proyecto cabía en la palma de su mano, el proceso creador de Van Eyck sería mucho más esforzado. A pesar de su idilio creativo con las formas circulares, las dudas sobre su acomodo con líneas rectas de inspiración urbana supondrán la búsqueda afanosa de una solución satisfactoria. Igualmente presente en los proyectos para la Iglesia Protestante de Driebergen o la Católica de la Haya, la articulación de formas y espacios de geometrías tan rotundas exige a Van Eyck un abundante desarrollo gráfico. Más de sesenta dibujos (6) registran la intensidad de la gestación del Pabellón de Arnhem. (Fig. 9)

Proyectado inicialmente como una construcción vegetal, a base de plantaciones sobre bastidores ligeros, acabó construyéndose con bloques de hormigón que definen cinco calles paralelas de 2,30 metros de ancho. Semicilindros cóncavos y convexos de idéntico material dilatan o comprimen el espacio donde el encuentro con las obras expuestas resulta, más que directo, inevitable. (7) La cubierta ligera, plana y traslúcida, quedaba flotando sobre el conjunto, dibujando en el aire la retícula que ordena su estructura portante. (Fig. 10)

Aldo van Eyck disfrutó del amplio reconocimiento de su Pabellón Sonsbeek, demolido el mismo año de su construcción. Aunque, como ocurriera en el caso de Rietveld, su destino final estaba aún por llegar. Cuarenta años

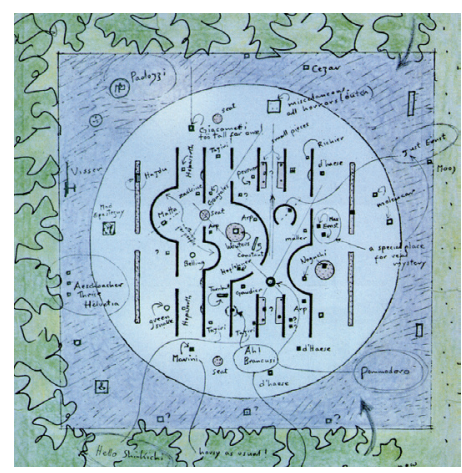

Fig. 9. Van Eyck, Aldo: Estudios preliminares para el pabellón de esculturas del Parque Sonsbeek de Arnhem, 1965. Aldo Van Eyck Archive. Fig. 10. Van Eyck, Aldo: Esquema final del pabellón de esculturas del Parque Sonsbeek de Arnhem, 1966. Aldo Van Eyck Archive.

Face-to-face with the lucidity of an inspired Rietveld, whose project fit into the palm of his hand, the creative process of Van Eyck would be much more strained. In spite of his creative idyll with circular forms, his doubts about their accommodation to straight lines of urban inspiration would suppose an onerous search for a satisfactory solution. Equally present in the projects for the Protestant Church of Driebergen or the Catholic Church of the Hague, the articulation of such round geometric forms demands of Van Eyck an abundant graphic development. More than 60 drawings (6) register the intensity of the gestation of the Arnhem Pavilion. (Fig. 9)

Initially projected as a green construction, based on plants covering light framework, he finally built with concrete blocks, defining five parallel streets, 2.30 metres wide. Concave and convex semi-cylinders of identical material dilate or compress the space where the encounter with the works exhibited results inevitable, more than direct. (7) A light-weight roof structure, flat and translucent, floated above the works, drawing in the air the reticule of the supporting structure. (Fig. 10)

Aldo van Eyck enjoyed wide recognition of his Sonsbeek Pavilion, demolished the same year as its construction. Nevertheless, as occurred in the case of Rietveld, its final destiny had yet to arrive. In 2006, forty years after its birth, the reconstruction of his well-remembered pavilion, unanimously considered as one of the masterpieces of the architect of Driebergen, was inaugurated. 
después de su alumbramiento, se inauguraba en 2006 la reconstrucción de su recordado pabellón, considerado unánimemente como una de las obras maestras del arquitecto de Driebergen. El proceso había comenzado tiempo atrás y el propio Van Eyck, fallecido en 1999, tuvo ocasión de elegir su emplazamiento en el parque del Museo Kröller-Müller, y de proponer algunas mejoras para la reedificación de su pabellón, especialmente lo tocante a la cubierta. Las obras estuvieron a cargo de su viuda, Hannie van Eyck, y de su colaborador Abel Blom. (Fig. 11)

Las tareas de reconstrucción no se detuvieron con la reedificación del pabellón Van Eyck y han alcanzado de nuevo al pabellón Rietveld, que acusaba el tiempo transcurrido en una estructura concebida para una duración de tan solo tres meses. En 2010, tras 45 años desde su instalación en los terrenos del Museo Kröller-Müller, el mal estado general forzó la intervención de la GBA (Government Buildings Agency), propietaria y responsable del mantenimiento del edificio. Tras evaluar el alcance de los daños, la única decisión posible fue su total reconstrucción. Las obras corrieron a cargo de Bertus

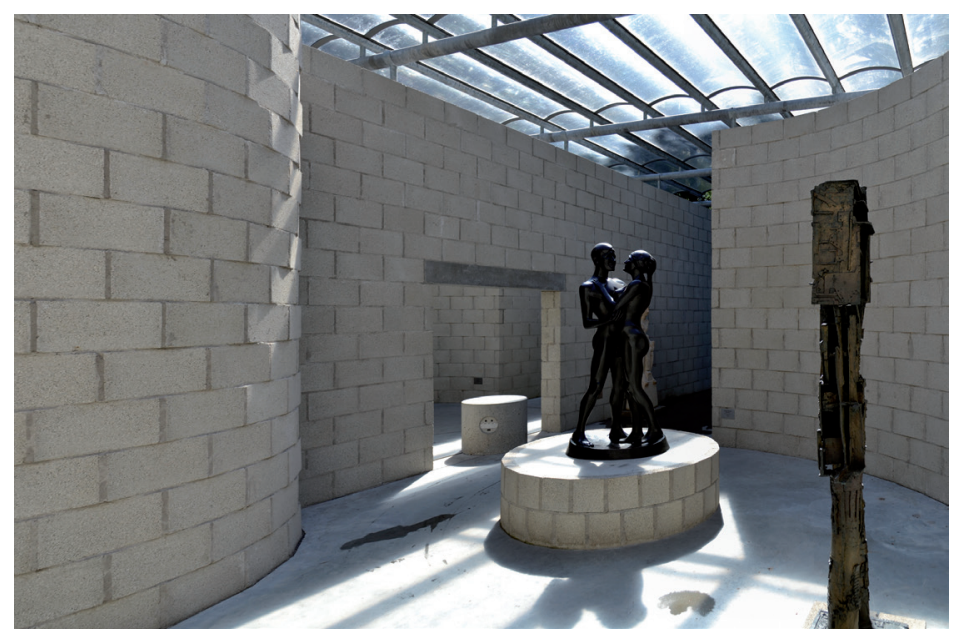

Fig. 11. Van Eyck, Aldo: Pabellón de esculturas, 1966. Reconstrucción en los jardines del Museo Kröller-Müller de Otterlo, 2006. Fotografía del autor, 2013.

The process had begun years before and Van Eyck himself, who died in 1999, had occasion to chose the location in the park of the Kröller-Müller Museum and to propose some improvements for the re-edification of his pavilion, especially those referring to the roofing. The works were in charge of his widow, Hannie van Eyck, and his collaborator, Abel Blom. (Fig. 11)

The reconstruction works did not cease with the re-edification of the Van Eyck Pavilion and started once again in the Rietveld Pavilion, a structure conceived for a duration of only three months, which had suffered from the passing of time. In 2010, 45 years after its installation in the grounds of the Kröller-Müller Museum, its general faulty shape forced the intervention of the GBA (Government Buildings Agency), proprietor and body in charge of the maintenance of the building. After evaluating the extent of the damages, the only possible decision was its total reconstruction. Bertus Mulder was in charge of the works, which would achieve an exact replication of the work of Rietveld, although only part of the original wood beams of the roof and the steel structure could be used. All the other materials are completely new. (Fig. 12)

While the International Sonsbeek Foundation announced a new date with contemporary art in 2016, the periodic reconstruction related to the buildings seems to have no end. After the death of Wiek Röling (2011), author of the floating pavi- 
Mulder, que lograría una réplica exacta de la obra de Rietveld, si bien solo pudo reutilizar parte de las vigas de madera de cubierta y la estructura de acero. El resto de materiales es completamente nuevo. (Fig. 12)

Mientras la Fundación Internacional Sonsbeek anuncia para 2016 una nueva cita con el arte contemporáneo, los episodios reconstructores relacionados con sus edificios parecen no tener fin. Tras el fallecimiento en 2011 de Wiek Röling, autor del pabellón flotante para la exposición de 1986, su viuda ha comenzado una campaña para promover su reconstrucción en el lugar donde fue instalado originalmente, junto al pequeño lago del parque, donde su imagen reflejada completaba una estructura cúbica de extrema ligereza.

Efímero y perdurable. Una destacada pretensión de singularidad y la habitual indefinición de programas y funciones, han consolidado la tipología de los pabellones expositivos como uno de los más fértiles campos de experimentación arquitectónica de los últimos tiempos. No pocos arquitectos han dejado en sus pabellones valiosas muestras de su caudal creativo y de su compromiso con las vanguardias artísticas o tecnoló-

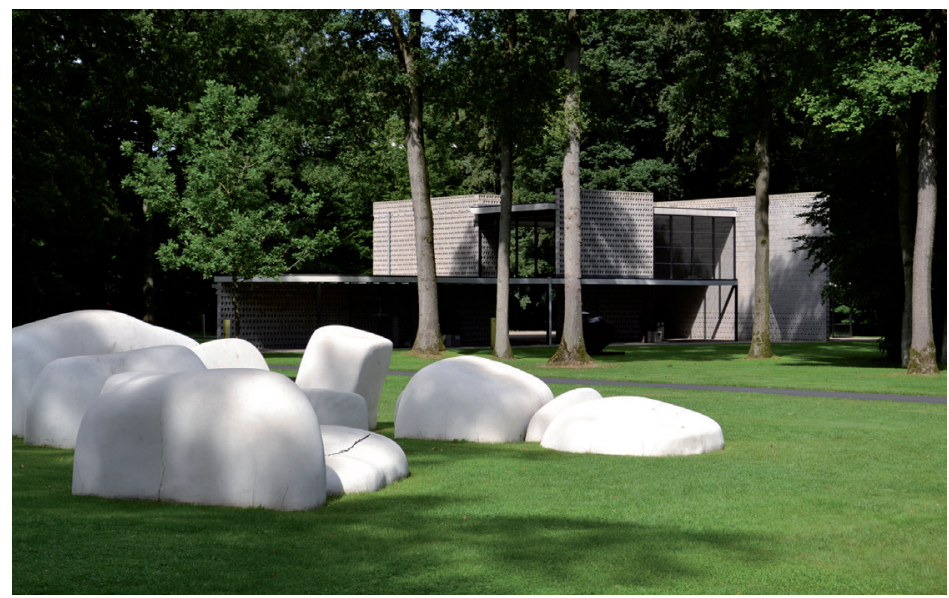

Fig. 12. Rietveld, Gerrit Th.: Pabellón de esculturas, 1955. Segunda reconstrucción, 2010. En primer término, Claassen, Tom: Rocky Lumps, 2005-06. Jardines del Museo Kröller-Müller de Otterlo. Fotografía del autor, 2013.

lion for the 1986 exhibition, his widow began a campaign to promote its reconstruction in the location it was originally situated in: next to the small lake in the park, where its reflected image completes the extremely light cubic structure.

Ephemeral and Everlasting. An outstanding pretention of singularity and the habitual lack of definition of programmes and functions have consolidated the typology of the exhibition pavilions as one of the most fertile fields of architectonic experimentation in recent times. Many architects have left valuable examples of their creative capacity and of their compromise with artistic and technological avant-guard in their pavilions, most of which disappeared in accordance with their ephemeral condition, although their inerasable memory forms part of our collective idea and of the recent history of architecture. (8) We exceptionally conserve the built memory of a few pavilions, some reconstructed in their original setting and others, re-edified in places far away. (9) The Sonsbeek pavilions of Rietveld and Van Eyck have been added to the brief relation of these constructions, recompensed with a second and even third existence. Considered treasures rediscovered, today we praise the indisputable quality of their approach and the eternal validity of their design above the occasion and temporality for which they were conceived. Nevertheless, one must consider that if their authors had been contemplating the possibility of permanence, the systems and materials chosen for their execution could have been different, or their attitudes might also have been quite distinct. 
gicas. La mayoría de ellos desaparecieron de acuerdo con su condición efímera, aunque su imborrable recuerdo forma parte de nuestro ideario colectivo y de la historia reciente de la arquitectura. (8) Excepcionalmente conservamos la memoria construida de algunos pabellones, unos reconstruidos en su localización original y otros reedificados en lugares alejados de su emplazamiento inicial. (9) Los pabellones Sonsbeek de Rietveld y Van Eyck se han sumado a la breve relación de estas construcciones recompensadas con una segunda, y hasta tercera, existencia. Contemplados como tesoros redescubiertos, elogiamos hoy la indiscutible calidad de su planteamiento y la imperecedera validez de su diseño por encima de la ocasión y la temporalidad para las que fueron concebidos. No obstante, cabe pensar si las actitudes de sus autores hubieran sido otras de haber contemplado la posibilidad de permanencia, o si los sistemas y materiales elegidos para su ejecución serían distintos.

La falta de autenticidad que algunos puristas pudieran encontrar en su visita a los clones de los pabellones Sonsbeek del Museo Kröller-Müller queda anulada si recordamos que ambos arquitectos aprobaron con entusiasmo la reedificación de sus obras, escogieron su emplazamiento y pudieron haber planteado variaciones de calado en su concepción o construcción. Probablemente una localización cercana, un uso idéntico y el unánime aplauso otorgado a los pabellones originales no sugirieron hacerlo. Revalidadas por sus creadores, las réplicas de sus arquitecturas originales posibilitan, como ellas, una enriquecedora experiencia arquitectónica y cualifican un escenario artístico de múltiples interferencias donde la exaltación del arte y la naturaleza ha alcanzado su máxima expresión.

The lack of authenticity that some purists could find in their visit to the clones of the Sonsbeek pavilions of the Kröller-Müller Museum is annulled if we remember that both architects enthusiastically approved the re-edification of their works: they chose their location and may have considered serious variations in their conception or construction. Probably a close location, an identical use, and the unanimous applause given the original pavilions did suggest doing this. Revalidated by their creators, the replications of their original architecture make a rich architectural experience possible and qualify an artistic setting of multiple interferences, where the exaltation of Art and Nature have reached their maximum expression. 


\section{NOTAS}

1. SCHULZE y WINDHORST, 2012.

2. Sam van Deventer, amigo y confidente de Helene Kröller-Müller relataba cómo, en contra de sus preferencias, Bremmer señaló la maqueta de Berlage diciendo "esto es arte" y, volviéndose hacia el trabajo de Mies van der Rohe espetó "y esto no".

3. Rietvled señaló esta circunstancia en un artículo publicado en el periódico Nieuwe Vlaardingsche Courant el 19 de octubre de 1960.

4. RIETVELD, 1939.

5. VAN EYCK, 1958. Defiende Van Eyck que la arquitectura es un arte fenomenológico, pero el arquitecto no es en absoluto un artista. Afirma después no haber visto nunca a Rietveld como arquitecto, sino como un artista, lo que verdaderamente le corresponde. 6. STRAUVEN, 1998. En su investigación sobre la obra de van Eyck, Strauven aproxima el número total de dibujos, si bien publica una veintena de ellos. En 1989 el conjunto completo fue expuesto en una exposición celebrada en la Bolsa de Berlage.

7. VAN EYCK, 1967. El edificio “debía tener algo de estrechez, de la densidad y de lo intrincado de lo urbano -de hecho, debe ser como-ciudad, en el sentido de provocar que gente y artefactos se encuentren, converjan y choquen allí inevitablemente-".

8. Algunos de los pabellones desaparecidos y más admirados son: el pabellón de las industrias de acero en la Feria de la Construcción de Leipzig, en 1913, obra de Bruno Taut y Franz Hoffmann; el de Vidrio en la exposición de Colonia, en 1914, de Bruno Taut. El pabellón de la URSS en la exposición internacional de las Artes Decorativas en París, en 1925, obra de Konstantin Melnikov; el de Finlandia en la Exposición Universal de Nueva York, en 1939, de Aino y Alvar Aalto; o el pabellón Philips en la exposición Universal de Bruselas, en 1958, obra de le Corbusier.

9. El Pabellón Alemán en la Exposición Internacional de Barcelona, en 1929, obra de Mies van de Rohe o el de Finlandia para la Bienal de Venecia de 1956, de Alvar Aalto, fueron reconstruidos en su mismo emplazamiento y reinaugurados en 1986 y 1990 , respectivamente. El Pabellón de L'Esprit Nouveau en la Exposición Internacional de las Artes decorativas de París, en 1925, obra de le Corbusier, se reedificó en 1977 en el Área Fiera de Bolonia; y el la República Española en la Exposición Internacional de París en 1937, de los arquitectos Josep Lluis Sert y Luis Lacasa, se construyó nuevamente en Barcelona en 1992.

\section{REFERENCIAS}

RIETVELD, Gerrit Thomas. 'Einige uitspraken over architectuur, gezien als één der plastische kunsten', en De 8 en Opbow, 1939. pp. 53-56. SCHULZE, Franz; WINDHORST, Edward. Mies van der Rohe: A Critical Biography. [New and Revised Edition].Chicago: The Univeristy of Chicago Press, 2012. pp. 38-43.

STRAUVEN, Francis. Aldo Van Eyck, The Shape of Relativity. Amsterdam: Architectura and Natura Press, 1998. pp. $495-506$.

VAN EYCK, Aldo. 'Kwadraten met een glimlach', en De Groene Amsterdammer. 17 de mayo de 1958.

VAN EYCK, Aldo. World Architecture 4. Londres, 1967.

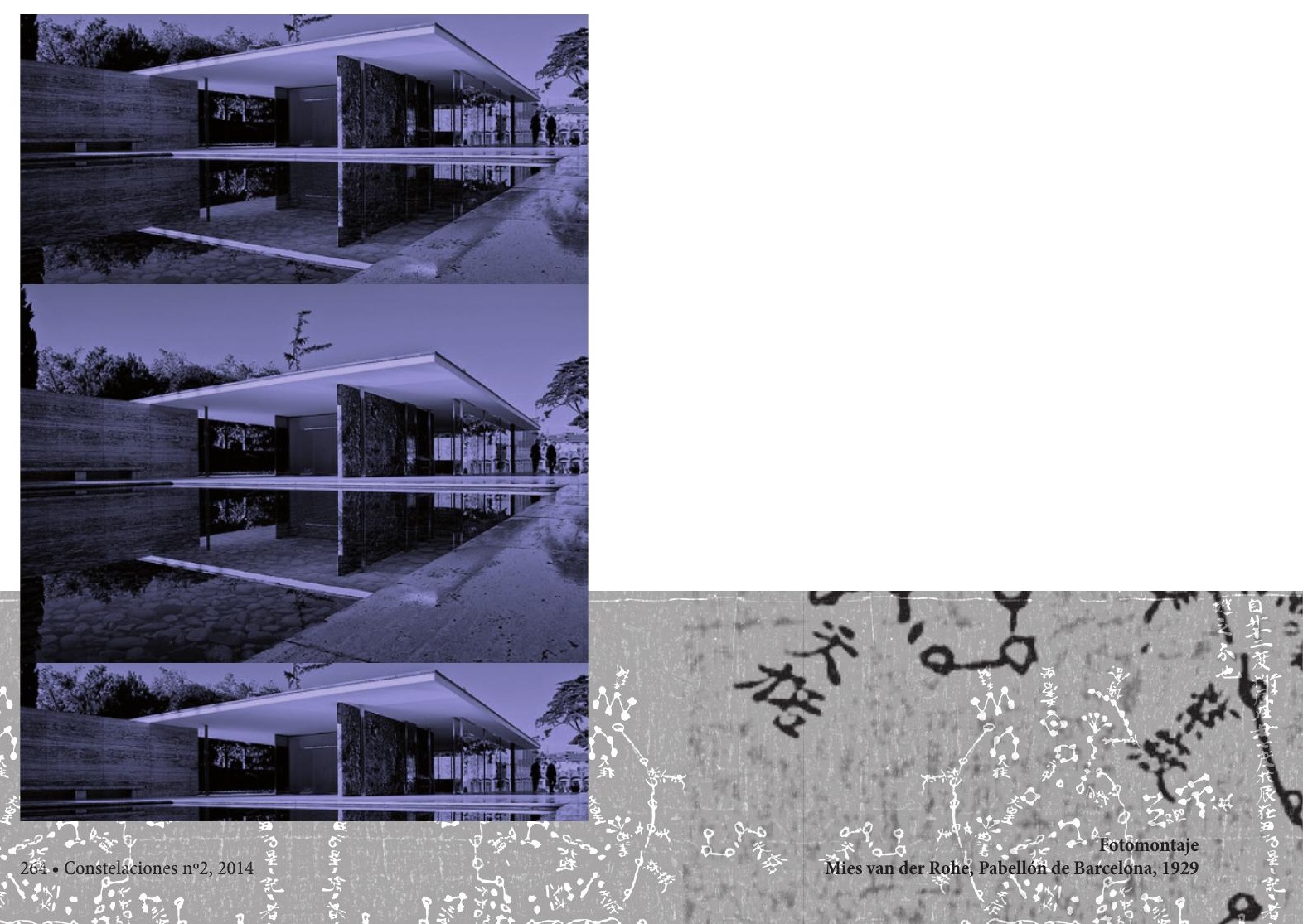




\section{NOTAS}

1. SCHULZE and WINDHORST, 2012.

2. Sam van Deventer, friend and confidant of Helene Kröller-Müller spoke of how, against his preferences, Bremmer showed him the model of Berlage, and commented: "this is art," while turning towards the work of Mies van der Rohe and spit out, "and this is not." 3. Rietvled pointed out this circumstance in an article published in the newspaper Nieuwe Vlaardingsche Courant, October 19 th, 1960.

4. RIETVELD, 1939.

5. VAN EYCK, 1958. Van Eyck defends architecture as a remarkable art, but the architect is not at all an artist. He later affirms that he has never considered Rietveld as an architect, rather as an artist, which is what he really is.

6. STRAUVEN, 1998. In his investigation of the work of van Eyck, Strauven approaches the total number of drawings, but publishes only about twenty of them. In 1989, the entire group was exhibited in the Berlage stock market.

7. VAN EYCK, 1967. The building "should have something of the narrowness, density and intricacy of urbanity-in fact, it should be city-like, in the sense of provoking people and the artefacts found there to meet, converge, and inevitably bump into each other". 8. Some of the most-admired pavilions that have disappeared are: the pavilion of the steel industries in the Construction Fair in Leipzig, in 1913, work of Bruno Taut and Franz Hoffmann; the Glass Fair in Colonia, in 1914, Bruno Taut; the pavilion of the USSR in the International Exposition of Decorative Arts in Paris, in 1925, Konstantin Melnikov; the pavilion of Finland in the Universal Exposition in the United States in 1939, Aino y Alvar Aalto; or the Philips pavilion in the Universal Exposition in Brussels in 1958, work of le Corbusier.

9. The German Pavilion in the International Exposition in Barcelona, 1929, work of Mies van de Rohe or that of Finland for the Biennial of Venecia in 1956, Alvar Aalto, were reconstructed in their same places and re-inaugurated in 1986 and 1990 , respectively. The Pavilion of L'Esprit Nouveau in the International Exhibition of Decorative Arts in Paris, 1925, work of le Corbusier, was reedified in 1977 in the Área Fiera of Bolonia; and that of the Spanish Republic in the International Exposition in Paris in 1937, Josep Lluis Sert and Luis Lacasa, was constructed once again in Barcelona in 1992.

\section{REFERENCES}

RIETVELD, Gerrit Thomas. 'Einige uitspraken over architectuur, gezien als één der plastische kunsten', in De 8 en Opbow, 1939. pp. 53-56. SCHULZE, Franz; WINDHORST, Edward. Mies van der Rohe: A Critical Biography. [New and Revised Edition].Chicago: The Univeristy of Chicago Press, 2012. pp. 38-43.

STRAUVEN, Francis. Aldo Van Eyck, The Shape of Relativity. Amsterdam: Architectura and Natura Press, 1998. pp. 495-506.

VAN EYCK, Aldo. 'Kwadraten met een glimlach', in De Groene Amsterdammer. 17 de mayo de 1958.

VAN EYCK, Aldo. World Architecture 4. London, 1967.

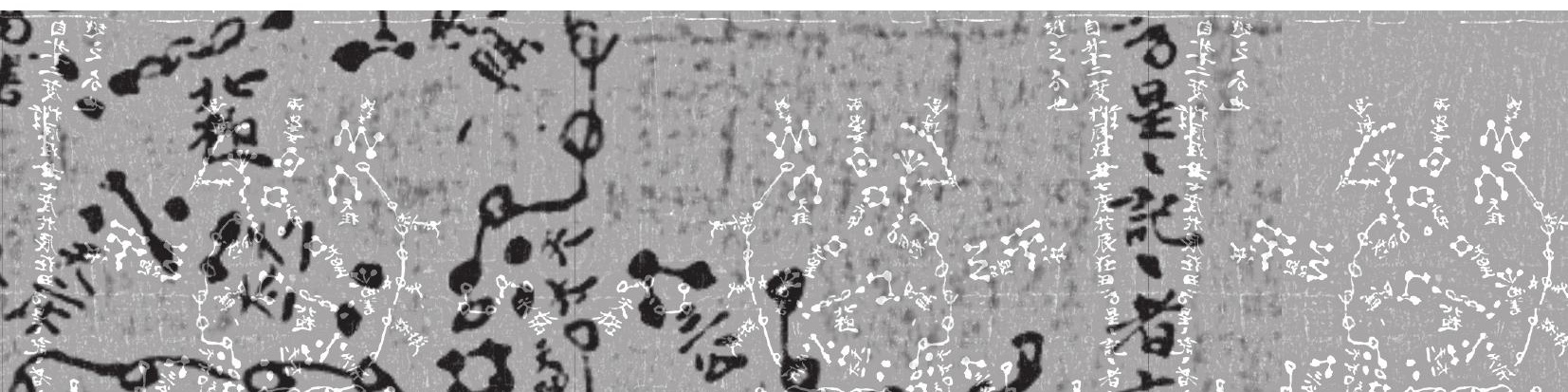

